\title{
Integration of Audio-Visual and Traditional Practices for Effective Classroom Teaching
}

\author{
Deepika Singh ${ }^{1}$, Mukul Kumar ${ }^{2 *}$ \\ ${ }^{1}$ S.K. College of Education, FCI Godham, Etah, India \\ ${ }^{2}$ State Key Laboratory of Space Weather, National Space Science Center, Chinese Academy of Sciences, \\ Beijing, China-100190 \\ ${ }^{*}$ Corresponding author email: mk.cas@yahoo.com \\ Received: 16 April 2018 / Accepted: 08 May 2018 / Published: 09 May 2018

\begin{abstract}
Education is one of the principal buildings blocks of the civilization. Since many centuries, teaching has been extensively accepted as a Nobel profession. The expected duty of teachers is to deliver their best in receiving and conveying the information correctly to their students in class and they do. But, in the modern era, when the young generation is conquered by the technological advancements, implementation of innovative teaching practices may help to improve the education system and can enhance the learning potential. The present article focuses on the integration of traditional and audio-video teaching practices.
\end{abstract}

\section{Introduction}

Implementing innovative teaching practices, we can strengthen the teaching, learning and the education system which will further lead to the social transformations (Nicolaides, 2012). The teaching and learning, which occur in the classroom and are considered as the social activities, establish a relationship between the instructor and students as well as with the materials, equipment, classroom environment and prospectus (SarÕçoban, 2010). The effectiveness of teaching is more often than not a measurement of the outcome of the students. Basically, it is well thought-out that the effective instructors are those who have a very good knowledge of the subject matter and who know how to deliver it appropriately and those who are able to establish a very good communication with their students in the class. An instructor should be receptive to the knowledge of his students and should be able to improve their existing knowledge and rectify their errors and misconceptions. An instructor should be a master in establishing communication with the students of lower as well as the higher mental standards in class.

A teacher usually tries to go after all the gears of effective teaching mentioned above and to find all these qualities at one place is really a blessing for the students. Again, the effectiveness of teaching suffers a few obstacles e.g. the instructor has sufficient knowledge of subject matter but remain unable to deliver in the appropriate way and the lack of proper communication between the students and instructor. Since hundreds of years, the most common practice in education has been teaching through lectures (Lammers \& Murphy 2002). This technique can be even more effective if get integrated with innovative techniques. The motivation of this article is to integrated audio-visual technique with the traditional teaching practice.

Copyright (C) 2018. The Author(s). Published by AIJR Publisher.

This is an open access article under Creative Commons Attribution-NonCommercial 4.0 International (CC BY-NC 4.0) license, which permits any non-commercial use, distribution, adaptation, and reproduction in any medium, as long as the original work is properly cited. 
Integration of Audio-Visual and Traditional Practices for Effective Classroom Teaching

\section{Importance of Audio-Visual Technique in Classroom Teaching:}

An old saying "I hear and I forget I see and I remember, I do and I understand" favors the significance of audio-visual devices in the education system. These devices contribute to enhancing the teaching-learning process and make it easier and interesting (Rasul et al. 2011). Audio-visual tools can be used for broadcasting the knowledge in the classroom integrated with the lecture using the smart boards for the explanations of the problems, side by side. Undoubtedly, the visualization of a problem helps students in improving the learning and understanding but to be applied in a pertinent way e.g. while delivering a lecture, an instructor can enhance the student learning effectiveness by utilizing animations or simulations of the problem based on the computer programs (Gargi et al. 2011; Keller et al. 2007, Grissom et al. 2003, Sayrol et al. 2001).

These animations or simulations help students to see what was invisible for them, to create an image of the problem in their mind and further to develop a problem-solving approach (Reed, 1987; Gobert and Buckley, 2000; Blake and Scanlon, 2007). While using the visualizations, it is advisable that the visualizations must serve their purpose and they should not perform just as the visual textbooks (Naps et. al., 2003). It is noticed that the lectures integrated with visualization have a significant impact on the learning effectiveness (Bratina et al. 2002). A study carried out by Rasul et al. (2011) shows that the audio-visual practice enhances the teaching and learning process, makes the teaching-learning process effective, provides deep and detailed knowledge and brings change in a classroom environment. Based on their study, a few recommendations were also made e.g. a training of using audio-video technique should be given to the teachers, teachers should plan before using the audio-visual techniques, universities can provide the audio-video facilities etc.

The applicability of audio-video technique has been widely studied in almost all the areas of science, humanities and engineering including Physics, Chemistry, Biology, Mathematics, Medical Sciences, Social sciences and machine learning etc. e.g. in college English teaching (Wang et al, 2011, Zhang 2011), college Physics teaching ( Xu and Liu, 2011; Hua and Hong, 2011), in mathematics (Beig et al. 2017), in music teaching (Hu, 2011) and in teaching the theory of machines ( $\mathrm{Li}$ and Xu 2011). N. D. Durham (1993) has reviewed the use of the audiovisual technique in biological anthropology. The audio-visual technique has also been examined by Akram et al. 2012 for teaching biology on the senior secondary level. All studies mentioned above carried out over the applications of the audio-visual technique in teaching reveal that the implementation of this innovative technology in teaching and education can enhance the quality of education.

\section{Conclusion}

Neither modern nor the traditional teaching methods can solve the purpose of providing quality teaching, independently. There is a call for integrating the traditional teaching techniques with the innovative technological advanced audio-visual techniques. This will not only improve the classroom environment but also help the students to develop an imagination of problems and further to develop the problem-solving approach. There is also a call of modifying the teaching methods on the school level to provide the quality education.

\section{How to Cite this Article:}

Singh, D., \& Kumar, M. (2018, May 09). Integration of Audio-Visual and Traditional Practices for Effective Classroom Teaching. Advanced Journal of Social Science, 3(1), 47-49. doi:10.21467/ajss.3.1.47-49

\section{References}

Akram S., Sufiana, Malik K., Use of audio-visual aids for effective teaching of biology at secondary school's level, Elixir International Journal, 50, 10597-10605, 2012.

Banerjee, G.; Patwardhan, M.; Mavinkurve, M., Teaching with visualizations in classroom setting: Mapping Instructional Strategies to Instructional Objectives, IEEE Fifth International Conference on Technology for Education (T4E), pp 176-183, 2013. 
Bieg M, Goetz T., Sticca F., BrunnerE., Becker E., Morger V., Hubbard K., Teaching methods and their impact on students' emotions in mathematics: An experience-sampling approach, ZDM Mathematics Education, 49:411-422, 2017.

Blake C. and Scanlon E., Reconsidering simulations in science education at a distance: Features of effective use, Journal of Computer Assisted Learning, vol. 23(6), p. 491- 502, 2007.

Bratina T. A., Hayes D., and Blumsack S. L., Preparing teachers to use learning objects, The Technology Source, Nov/Dec. 2002.

Durham N. D., Review of Audiovisual Materials for Use in Teaching Biological Anthropology, Yearbook of Physical Anthropology, 36:59-70, 1993.

Gobert J., and Buckley B., Introduction to model-based teaching and learning in science education, International Journal of Science Education, vol. 22 (9), p. 891-894, 2000.

Grissom S., McNally M.F. and Naps T., Algorithm visualization in CS education: comparing levels of student engagement, ACM Symposium on Software visualization, p. 87-94, 2003.

Hu, Z., Study on Innovation Mode of Quality Piano Curriculum in Senior Normal Universities and Colleges, in Education and Educational Technology, eds Wang, Y. , AISC 108, pp. 255-260, 2011.

Hua S. J., Hong L., A Demonstration Instrument Using Portable LED Display in College Physics Teaching in Education and Educational Technology, eds Wang, Y., AISC 108, pp. 183-186, 2011.

Keller, C.J.; Finkelstein, N.D.; Perkins, K. K., Assessing the effectiveness of a computer simulation in introductory undergraduate environments", AIP Conference Proceedings, vol 883, p. 121, 2007.

Lammers W. J., Murphy J. J., A profile of teaching techniques used in university classrooms, SAGE Publications, Vol 3(1), 54-67, 2002.

Li B., Xu C., Introducing Computer Simulation Technique into the Teaching of theory of Machines and Mechanisms Course, in "Education and Educational Technology" eds Wang, Y., AISC 108, pp. 583-589, 2011.

Naps T. L., Rößling G., Almstrum V., Dann W., Fleischer R., Hundhausen C., Korhonen A., Malmi L., McNally M., Rodger S., Velázquez-Iturbide J. A., Exploring the role of visualization and engagement in computer science education, ACM SIGCSE Bulletin, vol. 35(2), pp. 131-152, 2003.

Nicolaides A., Innovative teaching and learning methodologies for higher education Institutions, Educational Research (ISSN: 2141-5161) Vol. 3(8) pp. 620-626, August 2012.

Rasul, S.; Bukhsh, Q.; Batool, S. A study to analyze the effectiveness of audio-visual aids in teaching learning process at University level, Vol. 28, 78-81, 2011

Reed S. K., A structure-mapping model for word problems, Journal of Experimental Psychology, Learning, Memory Cognition, vol. 13 (1), pp. 124-139, 1987.

SarÕçoban A., Problems encountered by student-teachers during their practicum studies, Procedia Social and Behavioral Sciences 2, pp. 707-711, 2010.

Sayrol E., Gasull A., Salavedra J., Moreno A. and Vallverdú F., Graphical study of signals and systems, Acoustics, Speech, and Signal Processing Proceedings, vol. 5, p. 2705-2708, 2001.

Wang D., Ma Z., Zhang X., The Research on English Learning for PE Majors in "Education and Educational Technology" eds Wang, Y. , AISC 108 , pp. 23-27, 2011.

Xu X., Liu Z., The Research of Audio-Visual Teaching in College Physics Teaching Practice, in "Education and Educational Technology" eds Wang, Y., AISC 108, pp. 237-241, 2011.

Zhang X., Visualization of Robert Frost's Poetry in the EFL Classroom in "Education and Educational Technology" eds Wang, Y. , AISC 108, pp. 89-93, 2011.

Publish your research article in AIJR journals-

$\checkmark$ Online Submission and Tracking

$\checkmark$ Peer-Reviewed

$\checkmark$ Rapid decision

$\checkmark \quad$ Immediate Publication after acceptance

$\checkmark$ Articles freely available online

$\checkmark \quad$ Retain full copyright of your article.

Submit your article at journals.aijr.in
Publish your books with AIJR publisher-

$\checkmark$ Publish with ISBN and DOI.

$\checkmark$ Publish Thesis/Dissertation as Monograph.

$\checkmark$ Publish Book Monograph.

$\checkmark$ Publish Edited Volume/ Book.

$\checkmark$ Publish Conference Proceedings

$\checkmark \quad$ Retain full copyright of your books.

Submit your manuscript at books.aijr.org 